\title{
NOTE
}

\section{Effects of low air temperature on Laminaria digitata in south-western Scotland}

\author{
Christopher D. Todd ${ }^{1}$ and J. R. Lewis ${ }^{2}$ \\ 'Department of Marine Biology, Gatty Marine Laboratory, University of St. Andrews, St. Andrews, Fife KY16 8LB, Scotland \\ ${ }^{2}$ Ex - Wellcome Marine Laboratory, University of Leeds, Robin Hood's Bay, North Yorkshire YO22 4SL, England
}

ABSTRACT: Effects of severe frosts of the winter of $1981-82$ on Laminaria digitata (L.) populations in south-west Scotland are reported. In addition, some inferences are drawn with respect to possible effects of low temperature on vertical distributions of the macroalga Bifurcaria bifurcata (Stack L.) and the anemone Anemonia viridis (Forskal).

There has been a renewal of interest in the importance of physical factors in determining vertical distributions of intertidal organisms, especially macroalgae (e.g. Schonbeck and Norton, 1978, 1980; Dring and Brown, 1982; Druehl and Green, 1982). Undoubtedly, most workers would concur with Connell (1961) in concluding that upper limits of distribution are set primarily by physical factors, while lower limits are determined largely by biological interactions.
In the British Isles the winter of 1981-82 was characterised by repeated occurrence of anomalously low temperatures, particularly in December and January. However, the mean temperatures for these months were near normal. Observations of some shores in Argyll, south-west Scotland in February 1982 revealed that the severe frosts of the previous 2 mo had no effect on high-shore algae - e.g. Pelvetia canaliculata (L.) and Fucus spiralis (L.) - in agreement with the work of Schonbeck and Norton (1978), but had decimated the upper regions of some local populations of the lowshore kelp Laminaria digitata (Huds.), especially that at Cuan Ferry, Seil Island.

The shores at Cuan Ferry and Clachan Seil on Seil Island, Argyll have been visited monthly since Febru-

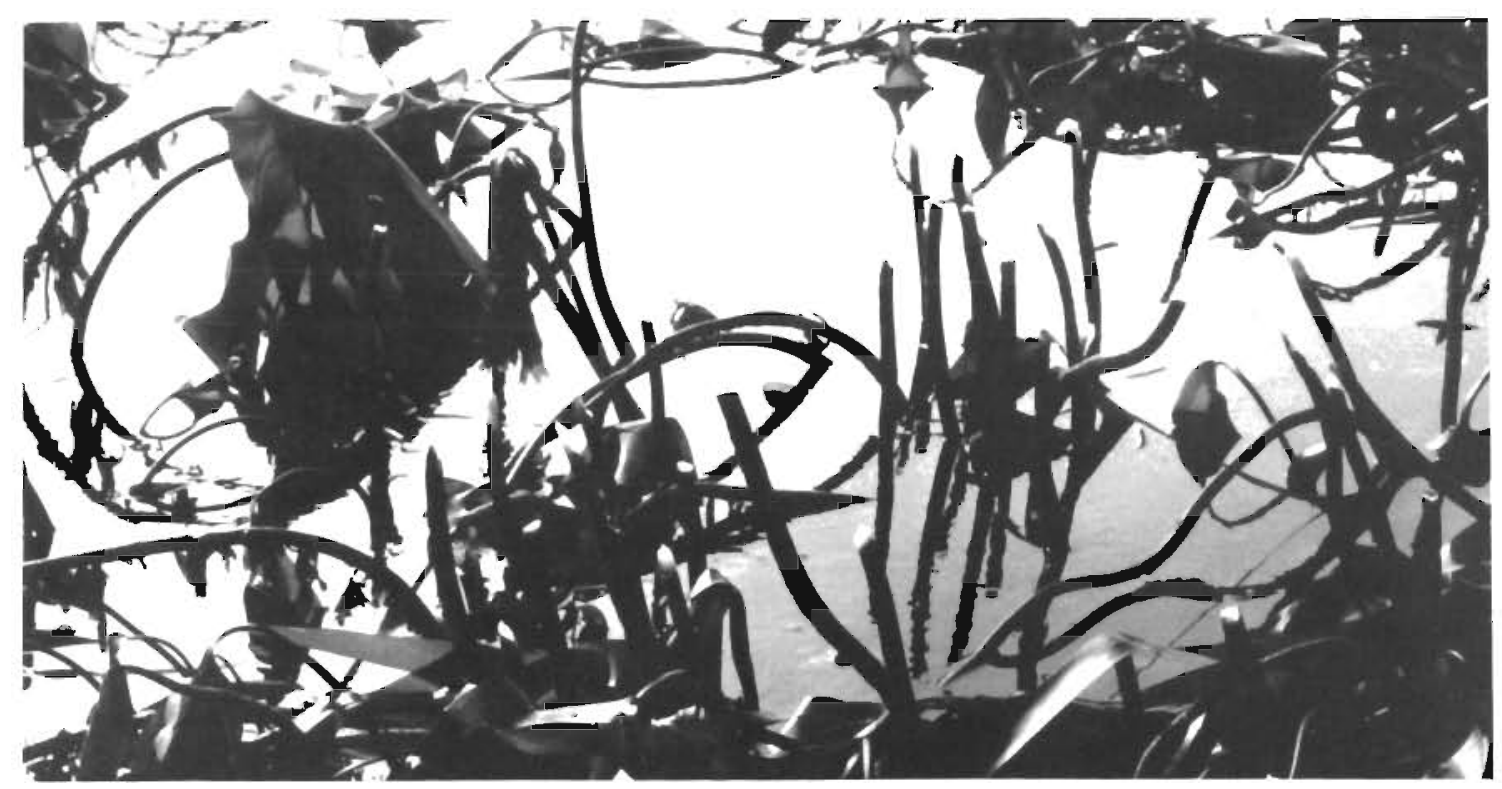

Fig. 1. Detail of the Laminaria stand at Cuan Ferry, Argyll illustrating the extent of algal mortality. Note the typical calmness of the sea-surface 
ary 1980. The sudden and dramatic change which overcame the Laminaria digitata populations in the vicinity of Cuan Ferry between January and February 1982 was quite striking. Fig. 1 illustrates the condition of $L$. digitata in March 1982. Nearly all the plants with the exception of those lowest on the shore, and of young plants with thin, less stiff stipes - had been destroyed. This was not the normal defoliation process of Laminaria, nor was it due to grazing. The local population of the kelp-grazing echinoid Echinus esculentus L. is extremely sparse, and domestic animals (such as sheep and cows) and deer, which are known to graze periodically intertidal macroalgae $(\mathrm{H}$. Powell, pers. comm.), were apparently absent throughout this period. The extent, sharpness, and evenness of the cutback of these Laminaria populations suggest that the extreme temperatures and frosts of December 1981 and January 1982 might be responsible.

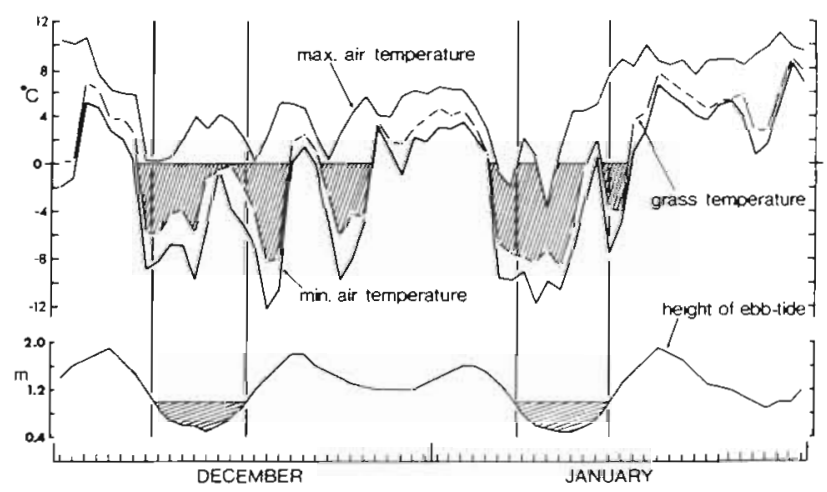

Fig. 2. Meteorological data for December 1981 and January 1982 as recorded at Dunstaffnage Marine Research Laboratory, Oban. Periods of sub-zero temperatures coincident with the lowest spring tides are highlighted

Maximum and minimum air temperatures and grass temperature (at $0900 \mathrm{GMT}$ ) at the S.M.B.A. laboratory at Dunstaffnage, Argyll, some $30 \mathrm{~km}$ north of Cuan Ferry are illustrated for December 1981 and January 1982 in Fig. 2 together with the height above chart datum of the ebb tides on corresponding dates. The tidal heights are those predicted for the period between 1800 GMT and 0600 GMT on each date. It is clear that the major spring tides of each month (when the Laminaria populations would have been largely uncovered) coincided with the most severe temperatures. The spring tides highlighted in Fig. 2 are those for which the predicted height above chart datum $\leqslant 1.0 \mathrm{~m}$ and these fell between December 9-16 and January $8-15$. For these 2 periods the predicted time of low-water was 2148-0226 GMT and 2229-0250 GMT, respectively. During both these periods at least the upper part of the L. digitata zone would have been subjected to extreme air-frosts around midnight on several consecutive days. Indeed, in January even the midday ebb tide would have exposed kelp to subzero temperatures.

The habit of Laminaria digitata is such that the basal meristematic growing region of the blade may be held up in the air on tidal emersion, with the bulk of the blade lying along the substratum or remaining immersed. This vulnerable part of the plant is therefore particularly open to air-frost damage and we expect that such damage would result in only the stipes remaining, as seen in Fig. 1. Young plants are more or less recumbent and thus less subject to frost damage arising from heat radiation to the air. Of the mature plants only those lowest on the shore remained intact: presumably these remained immersed throughout the detrimental ebb-tide periods.

Clachan Seil $(5 \mathrm{~km}$ north of Cuan Ferry) is a very sheltered tidal narrow of some $30 \mathrm{~m}$ width between Seil Island and the Argyll mainland (see Lewis, 1964, Ch. 1 for a full description). There are tidal sills at both the northern and southern extremities of the narrows and as a result the spring tides ebb to the same level between the sills irrespective of open coast fluctuations. In contrast to the situation at Cuan Ferry, within Clachan Seil, the bulk of the Laminaria digitata and L. saccharina (L.) populations remain largely or totally submerged on all tides so that the kelp populations here were totally unaffected during the period in question.

It is important to emphasise that the detrimental effects were both local in occurrence and transient in duration. During the succeeding summer months the typical Laminaria stipe epiflora 'bloomed' with large stands of Palmaria palmata (L.) especially flourishing on the decaying stipes, presumably due to the reduction of shading. By December 1982 the kelp canopy was re-established and appeared normal.

Summarizing a compilation of data throughout the British Isles on the effects of the severe winter of 1962-63, Crisp (1964) did not report any extensive, widespread or 'permanent' effects on intertidal algae. He suggested that it is temperature anomaly - rather than the temperature itself - which will be the critical factor determining any such impact. Severe low temperature anomalies are most likely to occur during high pressure periods with negligible winds, and might perhaps be intensified locally in enclosed areas (such as sea-lochs, as in the present case) where additionally the lower-shore ameliorating influence of ground-swell and wave-action would be missing. The detrimental effects of the severe frosts of the winter of 1981-82 on Laminaria digitata do not, however, appear to have been restricted to the unusually protected shore at Cuan Ferry. We have reports of similar mortality of L. digitata at Torness, Lothian (H. Powell, pers. 
comm.) and in Fife, on the east coast of Scotland (D. C. Weeks, pers. comm.).

Intertidal species living on the open rock must be tolerant of the wide range of aerial conditions experienced in both winter and summer. The many observations on how sharply upper limits of distribution respond to changes in wave-splash and aspect direct attention generally to the overriding importance of excessive heat, light or desiccation - or some combination thereof. In the case of pool-dwelling species the general assumption is simpler: they are intolerant of desiccation. Therefore, it comes as some considerable surprise, initially, to find species which are primarily pool-dwelling at their northern geographical limits in the British Isles, e.g. the alga Bifurcaria bifurcata (Stackh.) and the anemone Anemonia viridis (= sulcata) (Forskal), living on the open rock surface of the lower shore in northern and north-western Spain, thereby demonstrating a most unexpected tolerance to desiccation and high aerial temperature. Such observations (by J.R.L.), regarded as normal in these regions, must lead to re-consideration of what it is they avoid by living in pools in the north. Although we have no experimental data it seems most probable that intolerance of low air temperatures increasingly restricts them to pools or sublittoral levels towards their northern geographical limits.

By contrast, Laminaria digitata, an essentially sublittoral species is, in the British Isles, susceptible to aerial conditions generally. While the scarcity of observations of cold-death may be due to the fact that low spring tides in calm weather are more likely in summer (leading to frequent heat-death) than they are in winter (when cold-death may occur), this could also be a reflection of the species' greater boreal affinities.

Acknowledgements. We thank Mr. H. T. Powell for provision of S.M.B.A. meteorological data, and permission of the Director to publish these. Grant support from the Natural Environment Research Council is gratefully acknowledged.

\section{LITERATURE CITED}

Connell, J. H. (1961). The influence of interspecific competition and other factors on the distribution of the barnacle Chthamalus stellatus. Ecology 42: 710-723

Crisp, D. J. (ed.) (1964). The effects of the severe winter of 1962-63 on marine life in Britain. J. Anim. Ecol. 33: $165-208$

Dring, M. J., Brown, F. A. (1982). Photosynthesis of intertidal brown algae during and after periods of emersion: a renewed search for physiological causes of zonation. Mar. Ecol. Prog. Ser. 8: 301-308

Druehl, L. D., Green, J. M. (1982). Vertical distribution of intertidal seaweeds as related to patterns of submersion and emersion. Mar. Ecol. Prog. Ser. 9: 163-170

Lewis, J.R. (1964). Ecology of rocky shores. English Universities Press

Schonbeck, M., Norton, T. A. (1978). Factors controlling the upper limits of fucoid algae on the shore. J. exp. mar. biol. Ecol. 31: 303-313

Schonbeck, M., Norton, T. A. (1980). Factors controlling the lower limits of fucoid algae on the shore. J. exp. mar. biol Ecol. 43: 131-150

Accepted for printing on November 18, 1983 